einstein

Official Publication of the Instituto Israelita

de Ensino e Pesquisa Albert Einstein

ISSN: 1679-4508 | e-ISSN: 2317-6385
How to cite this article:

Santos GG. Health education for the prevention of hypertensive disorders of pregnancy [letter]. einstein (São Paulo). 2020;18:eCE6076. http://dx.doi.org/10.31744/einstein journal/ 2020CE6076

\section{Received on:}

Aug 7, 2020

\section{Accepted on:}

Oct 8, 2020

\section{Copyright 2020}

\section{(cc) BY}

This content is licensed

under a Creative Commons

Attribution 4.0 International License.

\title{
Health education for the prevention of hypertensive disorders of pregnancy
}

\author{
Educação em saúde para prevenção de síndromes \\ hipertensivas da gestação \\ Gustavo Gonçalves dos Santos ${ }^{1}$ \\ ${ }^{1}$ Faculdade de Medicina, Universidade Estadual Paulista "Júlio de Mesquita Filho", Botucatu, SP, Brazil.
}

DOI: 10.31744/einstein_journal/2020CE6076

Dear Editor,

I have some considerations about the article "Epidemiology of hypertension in pregnant women". (1) The study is strongly based on evidence scientific, shows that health education is important in this scenario, and demonstrates that inappropriate individual and collective may be associated to onset of hypertension. The following factors are related to hypertension: advanced age, family history, preexisting hypertension, diabetes, obesity and consumption of ultra-processed foods, and strongly corroborate the need for health education. ${ }^{(2)}$ Nurses and physicians are the first professionals to have contact with the pregnant woman and should early identify the signs of complications of hypertensive pregnancy syndromes, using tools that guide the essential actions, not only in the biological aspect of the disease, but also addressing the pregnant woman in her singularity. ${ }^{(3-5)}$

Congratulations to the authors! The issue must be fully discussed, and publishing on this topic is a path for excellence.

\section{AUTHOR INFORMATION}

Santos GG: http://orcid.org/0000-0003-1615-7646

\section{REFERENCES}

1. Sousa MG, Lopes RG, Rocha ML, Lippi UG, Costa ES, Santos CM. Epidemiology of artherial hypertension in pregnants. einstein (São Paulo). 2020;18:eA04682. http://dx.doi.org/10.31744/einstein_journal/2020A04682

2. Thuler AC, Wall ML, Benedet DC, Souza SR, Souza MA. Preventive measures of hypertensive syndromes of pregnancy in primary care. J Nurs UFPE. 2018;12(4):1060-71.

3. Quental LL, Nascimento LC, Leal LC, Davim RM, Cunha IC. Educational practices with pregnant women at a Primary Health Care. J Nurs UFPE. 2017;11(Supl. 12):5370-81.

4. Cunha MA, Mamede MV, Dotto LM, Mamede FV. Assistência pré-natal: competências essenciais desempenhadas por enfermeiros. Esc Anna Nery. 2009;13(1):145-53.

5. Dias EG, Anjos GB, Alves L, Pereira SN, Campos LM. Ações do enfermeiro no pré-natal e a importância atribuída pelas gestantes. Rev Sustinere. 2018;6(1):52-62. 